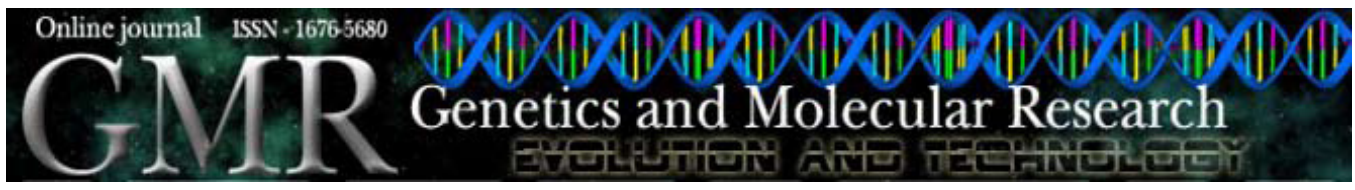

\title{
Genetic parameters in parents and hybrids of circulant diallel in popcorn
}

\author{
R.M. Rangel ${ }^{1}$, A.T. Amaral Júnior ${ }^{1}$, C.A. Scapim ${ }^{2}$, S.P. Freitas Júnior ${ }^{1}$ \\ and M.G. Pereira ${ }^{1}$ \\ ${ }^{1}$ Laboratório de Melhoramento Genético Vegetal, \\ Universidade Estadual do Norte Fluminense Darcy Ribeiro, \\ Campos dos Goytacazes, RJ, Brasil \\ ${ }^{2}$ Departamento de Agronomia, Universidade Estadual de Maringá, \\ Maringá, PR, Brasil \\ Corresponding author: A.T. Amaral Júnior \\ E-mail: amaraljr@uenf.br
}

Genet. Mol. Res. 7 (4): 1020-1030 (2008)

Received July 31, 2008

Accepted August 14, 2008

Published October 7, 2008

\begin{abstract}
With the aim of estimating genetic parameters and identifying superior popcorn combinations, 10 parents were crossed in a circulant diallel and evaluated together with the 15 resulting hybrids at two locations in two growing seasons for grain yield, number of broken plants, number of partially husked ears and popping expansion. The hybrids were less sensitive to environmental variations than the parents of the diallel in the 2003/2004 and 2004/2005 growing seasons. The genetic parameters suggested possible genetic gains for grain yield and popping expansion, mainly. Bidirectional dominance could have occurred for popping expansion. Heterobeltiosis for grain yield seems to be a common effect in popcorn. The intrapopulation breeding for popping expansion may offer superior genetic gains, but for grain yield, interpopulation breeding is required. The performance of UNB2U-C1 x BRS Angela indicated this hybrid for experimental cultivation in the northern and northwestern Fluminense region in Rio de Janeiro State, Brazil.
\end{abstract}

Key words: Combining ability; Diallel analysis; Heterosis; Zea mays L. 


\section{INTRODUCTION}

Rather surprisingly, popcorn breeding in Brazil is not a recent activity. It dates back to 1932, initiated at the Instituto Agronômico de Campinas (IAC). The first national variety was released in 1941, derived from mass selection cycles of the base population South American Mushroom (SAM), of South American, originated in the USA. However, studies in Brazil were only resumed in the beginning of the $1980 \mathrm{~s}$, culminating in the release of the modified single hybrid IAC-112 in 1988, derived from a combination of lines of the variety SAM with lines from the intervarietal hybrid Guarani x UFV Yellow (Sawazaki et al., 2000; Sawazaki, 2001) and, almost simultaneously, from the three-way hybrid Zélia, commercialized by Pioneer.

Since the 1990s, Brazil has made slow progress towards a self-sustained popcorn sector, although this observation applies strictly to breeding studies in the country, since releases of improved cultivars of Brazilian breeding programs are rare. There are a few exceptions: IAC-112, a modified simple hybrid, used by the company Hikari; IAC-125, a three-way hybrid derived from IAC-112, indexed in April 2006; BRS Angela, an open-pollinated variety, obtained by recurrent selection in the composite CMS-43, with the drawback of the white kernel color; RS-20, developed by IPAGRO and distributed by AGROESTE-SC, and UFVM2-Barão Viçosa (Rangel et al., 2007; Ricci et al., 2007).

The decline in importation is largely due to the cultivation of North American hybrids (for example, P608, P608 HT, P618, P621, and P625), indexed in Brazil and used by packaging companies, e.g., Yoki Aliments S.A., which restrict access to seed to the company's partner producers (Sawazaki, 2001; Sawazaki et al., 2003; Freitas Junior et al., 2006). In the 2006/2007 growing season, the three-way hybrid Jade, sold by Pioneer, was included among these options for the Brazilian seed market (Cruz and Pereira Filho, 2008).

In 1995, Sawazaki claimed that in Brazil, popcorn was not given the same attention as common maize, and that breeding throughout the country had made little progress due to the limited number of institutions and breeders dedicated to the crop (Sawazaki, 2001). In fact, in the 2006/2007 growing season, only 7 of 278 maize cultivars available on the market were popcorn. Moreover, from the maize cultivars bred by EMBRAPA, only one is a popcorn cultivar. This paradox contrasts with the economic value of the crop. The possibility of total mechanization and the absence of governmental price control boost the commercial value of popcorn to at least twice the price of common maize (Sawazaki et al., 2003; Daros et al., 2004; Freitas Júnior et al., 2006; Cruz and Pereira Filho, 2008).

In view of the high profitability for kernel producers as well as for the seed trade, versus the lack of cultivars developed by research institutions in Brazil, it is imperative that studies be conducted to evaluate base populations for the potentiality of hybrids, for use at an experimental level and a possible future release as superior cultivars. For this purpose, diallel analysis lends itself as viable alternative, even when the number of parents involved is high. In this situation, the circulant diallel is a particularly interesting methodology, as it requires only one sample of all possible parent combinations (Cruz et al., 2004).

Veiga et al. (2000) demonstrated the efficiency of circulant in comparison with complete diallels, to classify parents as well as estimate parameters of general and specific combining abilities. Ferreira et al. (2004) further verified the superior efficiency of the circulant over the complete diallel regarding the effects of general and specific combining abilities. 
The authors evaluated maize ear yield in a circulant diallel and stated that a reduction of $30 \%$ in the number of crosses did not affect the choice of the best parents and hybrids.

The present study was carried out to estimate genetic parameters in 10 parents and 15 hybrids derived from crosses in a circulant diallel that were evaluated in two locations and two growing seasons, to investigate the potential of the genotypes and to identify, a priori, adequate breeding strategies to obtain superior segregating materials.

\section{MATERIAL AND METHODS}

The following populations, previously selected by Freitas Júnior et al. (2006), were used to obtain hybrids in a circulant diallel: Beija-Flor, White-Viçosa, Viçosa-Viçosa, SE013Maringá, PA038-Maringá, BRS Angela, PR Ervália, Viçosa-UENF, UNB2U-C1, and UNB2UC2. As proposed by Kempthorne and Curnow (1961), the algorithm to establish the diallel crosses was based on three crosses per parent.

To establish the hybrid combinations, the 10 populations were grown in 6-m rows, paired in all necessary combinations, in a row-plant spacing of $1.00 \mathrm{~m}$ between rows and $0.40 \mathrm{~m}$ between plants, in March 2003. At flowering, approximately 100 crosses were performed between the rows so as to establish a sufficient quantity of hybrid seed to ensure the continuity of the process. Kraft paper bags were used to collect the pollen grains and for the proper pollination.

Hybrids, parents and controls (IAC-112, Produtor-Maringá, PR023-Maringá, UNB2U$\mathrm{C} 0$, and Viçosa) were evaluated in two contrasting localities in Rio de Janeiro State: Colégio Estadual Agrícola Antônio Sarlo, in Campos dos Goytacazes, and Experimental Station of PESAGRO-RIO of Itaocara, sown on 12/9/2004 and 12/14/2004 (2004/2005 growing season), respectively. The same treatments had been planted on 11/11/2003, in Campos dos Goytacazes and on 11/16/2003, in Itaocara, by Freitas Júnior et al. (2006). The results of these trials were designated 2003/2004 growing season. In each environment, 30 treatments (the 10 pre-selected parents, 15 hybrids and 5 controls) were arranged in a randomized block design with four replications, planted in single $10-\mathrm{m}$ rows $(1.00 \mathrm{~m}$ between-row spacing and $0.20 \mathrm{~m}$ in-row spacing).

The following traits were measured: grain yield (GY), expressed in $\mathrm{kg} / \mathrm{ha}$ of kernel weight after threshing; number of broken plants (NBP), determined by counting the plants with broken stem below the highest ear in each plot at harvest; number of partially husked ears (PHE), obtained by counting the partially husked ears, that is, where the tip of the ear was not covered with corn silk, in each plot at harvest, and popping expansion (PE), measured in the laboratory by a device developed by the Embrapa/Instrumentação Agropecuária. At a temperature of $270^{\circ} \mathrm{C}$, the popcorn kernels were popped for $2.5 \mathrm{~min}$ and evaluated by the ratio $\mathrm{mL} / \mathrm{g}$, that is, volume relative to mass of $30 \mathrm{~g}$ of popped kernels, with two replications for each plot.

The individual and joint analyses of variance were performed using the Genes software (Cruz, 2006). The joint analysis was based on the genetic-statistical model $Y_{\mathrm{ijkm}}=\mu+$ $(\mathrm{r} / \mathrm{y}) / \mathrm{e}_{\mathrm{jkm}}+\mathrm{g}_{\mathrm{i}}+\mathrm{e}_{\mathrm{j}}+\mathrm{y}_{\mathrm{k}}+\mathrm{gy}_{\mathrm{ik}}+\mathrm{ge}_{\mathrm{ij}}+\mathrm{ey}_{\mathrm{jk}}+\mathrm{gey}_{\mathrm{ijk}}+\xi_{\mathrm{ijkm}}$, considering the sources of variation of genotype and environment or location as fixed, and the source of variation year as random effect, where: $\mathrm{Y}_{\mathrm{ijkm}}=$ phenotypic value of the observation ijkm of genotype $\mathrm{i}$, year k and environment $\mathrm{j}$ in block $\mathrm{m} ; \mu=$ general mean; $(\mathrm{r} / \mathrm{y}) / \mathrm{e}_{\mathrm{jkm}}=$ effect of block $\mathrm{m}$ within year $\mathrm{k}$ at environment $j ; g_{i}=$ effect of genotype $i ; e_{j}=$ effect of environment $j ; y_{k}=$ effect of year $k$; $g_{i k}=$ effect of interaction between genotype $\mathrm{i}$ and year $\mathrm{k} ; \mathrm{ge}_{\mathrm{ij}}=$ effect of interaction between genotype $\mathrm{i}$ and environment $\mathrm{j}$; $\mathrm{ey}_{\mathrm{jk}}=$ effect of interaction between environment $\mathrm{j}$ and year $\mathrm{k}$; gey $_{\mathrm{ijk}}=$ ef- 
fect of the interaction among genotype $\mathrm{i}$, environment $\mathrm{j}$ and year $\mathrm{k}$, and $\xi_{\mathrm{ijkm}}=$ experimental error associated with observation ijkm $\sim \mathrm{N}\left(0, \sigma_{\mathrm{e}}^{2}\right)$ (Hallauer and Miranda Filho, 1995). The homogenous variance test was performed before doing the joint analysis.

The phenotypic means were used to estimate the following genetic parameters:

a) mean phenotypic variance,

$$
\hat{\sigma}_{f(\bar{X})}^{2}=\hat{\Phi}_{g}+\frac{\hat{\sigma}_{R}^{2}}{e r y},
$$

where $\hat{\Phi}_{g}=$ quadratic component that expresses genotypic variability in the treatment means, $\mathrm{r}=$ number of replications, $\mathrm{e}=$ number of environments, and $\mathrm{y}=$ number of years;

b) genotypic variability,

$$
\hat{\Phi}_{g}=\frac{M S G-M S G \times \text { Year }}{e r y}
$$

(Equation 2)

where MSG is the mean square of the genotype,

c) residual variance,

$$
\hat{\sigma}_{r(\bar{x})}^{2}=\frac{M S R}{e r y}
$$

where MSR is the mean square of the error,

d) variance of genotype-by-location interaction,

$$
\hat{\sigma}_{g e}^{2}=\frac{M S G \times \text { Year }-M S R}{e r} ;
$$

e) coefficient of genotype determination,

$$
\hat{H}_{\bar{X}(\%)}^{2}=\frac{\hat{\Phi}_{g}}{\hat{\sigma}_{f(\bar{x})}^{2}} \times 100 ;
$$

variation index,

$$
\hat{I}_{v}=\sqrt{\frac{\hat{\Phi}_{g}}{M S R}},
$$

and relative heterosis,

$$
\hat{H}_{M P(\%)}=\frac{\bar{F}_{1}-M P}{M P} \times 100,
$$

where $\bar{F}_{1}$ is the mean of the hybrid combinations and $M P$ the mean of the parents (Hallauer and Miranda Filho, 1995; Cruz et al., 2004). 


\section{RESULTS AND DISCUSSION}

With exception of NBP, the mean squares of the source of variation per year were significant (at $1 \%$ probability) for the other traits (Table 1), indicating differences between the means of the 2003/2004 and 2004/2005 growing seasons.

\begin{tabular}{|c|c|c|c|c|c|}
\hline \multirow[t]{2}{*}{ Source of variation } & \multirow[t]{2}{*}{ d.f. } & \multicolumn{4}{|c|}{ Mean squares } \\
\hline & & GY & NBP & PHE & PE \\
\hline $\begin{array}{l}\text { Replications/Locations x } \\
\text { Year (R / L x Y) }\end{array}$ & 12 & $501,434.4800$ & 238.5986 & 8.2743 & 6.0210 \\
\hline Year $(\mathrm{Y})$ & 1 & $58,975,130.2100^{* *}$ & $33.0750^{\text {ns }}$ & $23.8520^{* * *}$ & $123.4240^{* * *}$ \\
\hline Location (L) & 1 & $29,363,413.3300^{* *}$ & $2,641.4083^{\mathrm{ns}}$ & $3.8520^{\mathrm{ns}}$ & $206.1940^{* *}$ \\
\hline LxY & 1 & $7,648,225.2100^{* *}$ & $5,440.5333^{* *}$ & $46.2520^{* *}$ & $116.2300^{* *}$ \\
\hline Treatment (T) & 29 & $1,596,583.6600 * *$ & $196.7100^{* *}$ & $4.6701^{\mathrm{ns}}$ & $316.1132^{* *}$ \\
\hline Genotype (G) & 24 & $1,879,863.7700^{* *}$ & $184.0089^{* *}$ & $5.0837^{\mathrm{ns}}$ & $302.2309^{* * *}$ \\
\hline Parents (P) & 9 & $1,556,404.6000^{*}$ & $319.4972^{*}$ & $6.4506^{\text {ns }}$ & $406.5829^{* * *}$ \\
\hline Hybrids $(\mathrm{H})$ & 14 & $553,272.0700 * *$ & $100.2470^{\text {ns }}$ & $4.0416^{\text {ns }}$ & $255.2566^{* *}$ \\
\hline $\mathrm{PxH}$ & 1 & $23,363,280.0100^{* *}$ & $137.2816^{* *}$ & $7.3704^{* *}$ & $20.7018^{* *}$ \\
\hline Control (C) & 4 & $269,014.3750^{\text {ns }}$ & $317.1437^{*}$ & $1.3437^{\mathrm{ns}}$ & $478.4059^{* *}$ \\
\hline $\mathrm{G} \times \mathrm{C}$ & 1 & $108,138.3700^{* *}$ & $19.8016^{\text {ns }}$ & $8.0504^{* * *}$ & $0.1176^{\mathrm{ns}}$ \\
\hline T x Y & 29 & $277,472.4500^{* *}$ & $50.2775^{\text {ns }}$ & $3.6150^{\text {ns }}$ & $16.2508^{* *}$ \\
\hline GxY & 24 & $317,819.1500^{* *}$ & $50.6922^{*}$ & $3.3854^{\mathrm{ns}}$ & $14.3995^{* * *}$ \\
\hline $\mathrm{PxY}$ & 9 & $326,986.2700^{* *}$ & $55.8194^{\mathrm{ns}}$ & $2.2006^{\text {ns }}$ & 11.7054* \\
\hline $\mathrm{H} \times \mathrm{Y}$ & 14 & $132,624.7500^{\mathrm{ns}}$ & $47.2875^{\text {ns }}$ & $4.3821^{*}$ & $16.0639^{* *}$ \\
\hline $\mathrm{PxH} \times \mathrm{Y}$ & 1 & $2,828,036.7600^{* *}$ & $52.2150^{\text {ns }}$ & $0.0937^{\text {ns }}$ & $15.3440^{\text {ns }}$ \\
\hline $\mathrm{Cx} \mathrm{Y}$ & 4 & $91,972.1870^{\text {ns }}$ & $37.5437^{\mathrm{ns}}$ & $5.8312^{\text {ns }}$ & $28.9126^{* *}$ \\
\hline $\mathrm{GxC} \times \mathrm{Y}$ & 1 & $51,152.6700^{\text {ns }}$ & $91.2600^{\mathrm{ns}}$ & $0.2604^{\mathrm{ns}}$ & $10.0362^{\text {ns }}$ \\
\hline $\mathrm{T} \times \mathrm{L}$ & 29 & $218,012.2600^{\mathrm{ns}}$ & $80.2402^{\mathrm{ns}}$ & $2.0632^{\mathrm{ns}}$ & $14.2311^{\mathrm{ns}}$ \\
\hline Gx L & 24 & $240,434.3400^{\mathrm{ns}}$ & $72.9818^{\mathrm{ns}}$ & $2.1016^{\mathrm{ns}}$ & $15.6245^{\text {ns }}$ \\
\hline $\mathrm{PxL}$ & 9 & $106,229.6000^{\mathrm{ns}}$ & $88.1000^{\text {ns }}$ & $2.2784^{\mathrm{ns}}$ & $12.8382^{\text {ns }}$ \\
\hline $\mathrm{H} \times \mathrm{L}$ & 14 & $128,625.1900^{\mathrm{ns}}$ & $67.0875^{\text {ns }}$ & $2.1130^{\mathrm{ns}}$ & $18.2880^{\text {ns }}$ \\
\hline $\mathrm{PxH} \times \mathrm{L}$ & 1 & $3,013,605.0100^{* *}$ & $19.4400^{\text {ns }}$ & $0.3504^{* * *}$ & $3.4126^{\text {ns }}$ \\
\hline $\mathrm{C} \times \mathrm{L}$ & 4 & $106,409.0620^{\mathrm{ns}}$ & $37.1687^{\text {ns }}$ & $2.1562^{\mathrm{ns}}$ & $7.1466^{\mathrm{ns}}$ \\
\hline $\mathrm{G} \times \mathrm{C} \times \mathrm{L}$ & 1 & $126,295.0400^{* *}$ & $426.7266^{* * *}$ & $0.7704^{* *}$ & $9.1266^{* *}$ \\
\hline T x L x Y & 29 & $201,376.0700^{* *}$ & $61.1497^{*}$ & $2.4460^{\text {ns }}$ & $14.3138^{* * *}$ \\
\hline Gx L x Y & 24 & $221,705.0400^{* *}$ & $61.6443^{* * *}$ & $2.6141^{\text {ns }}$ & $8.6033^{*}$ \\
\hline$P \times L \times Y$ & 9 & $162,290.0200^{*}$ & $123.0444^{* * *}$ & $2.3951^{\text {ns }}$ & $9.8374^{\mathrm{ns}}$ \\
\hline H x L x Y & 14 & $230,850.8500^{*}$ & $24.5017^{\text {ns }}$ & $2.9392^{\text {ns }}$ & $8.0663^{\mathrm{ns}}$ \\
\hline PxH $\mathrm{x} L \mathrm{x} Y$ & 1 & $628,398.8400^{*}$ & $29.0400^{\mathrm{ns}}$ & $0.0337^{\text {ns }}$ & $5.0142^{\mathrm{ns}}$ \\
\hline $\mathrm{C} \times \mathrm{LxY}$ & 4 & $129,251.2500^{\mathrm{ns}}$ & $70.1687^{\mathrm{ns}}$ & $2.0437^{\mathrm{ns}}$ & $50.8114^{* *}$ \\
\hline Gx Cx Lxy & 1 & $1,980.1700^{\text {ns }}$ & $13.2016^{\mathrm{ns}}$ & $0.0204^{\text {ns }}$ & $5.3770^{\text {ns }}$ \\
\hline Error & 348 & $102,340.7000$ & 34.9664 & 2.5932 & 5.4761 \\
\hline General mean & & $1,222.87$ & 13.86 & 2.28 & 19.32 \\
\hline Genotype mean & & $1,229.58$ & 13.95 & 2.34 & 19.33 \\
\hline Control mean & & $1,189.31$ & 13.41 & 2.00 & 19.29 \\
\hline CVe (\%) & & 26.16 & 42.64 & 70.33 & 12.10 \\
\hline
\end{tabular}

$\mathrm{GY}=$ grain yield, in $\mathrm{kg} / \mathrm{ha} ; \mathrm{NBP}=$ number of broken plants; $\mathrm{PHE}=$ partially husked ears; $\mathrm{PE}=$ popping expansion, in $\mathrm{mL} / \mathrm{g} .{ }^{* *}$ Significant at $1 \%$ probability by the $\mathrm{F}$ test. ${ }^{*}$ Significant at $5 \%$ probability by the $\mathrm{F}$ test. $\mathrm{ns}=$ not significant. d.f. $=$ degrees of freedom. 
For location, the significance (at 1\% probability) for GY and PE only shows that, in principle, different programs should be conducted for each location. Considering only popping expansion, Vendruscolo et al. (2001) evaluated 15 genotypes (varieties and intervarietal hybrids) in 15 localities in the Central-South region of Brazil, and observed an environmental influence on PE. This trait was reported to be strongly location-related, contributing to the supposition of quantitative inheritance. The environmental influence on popping expansion of popcorn is explained by the fact that not all genes that contribute to endosperm hardness contribute to popping expansion (Robbins Jr. and Ashman, 1984).

With regard to the sources of variation for treatment and genotype, the differences of all traits but PHE were significant, which implies the absence of undesirable variations in relation to partially husked ears and indicates the existence of considerable genetic variability in the genotypes evaluated. Compared to the control performance, no significant differences were determined (5\% probability) for GY and PHE, suggesting that these genotypes were genetically less dissimilar than the set of parents and hybrids of the diallel.

In the analysis of the genotype-by-control, the traits GY and PHE were significant by the $\mathrm{F}$ test, leading to the conclusion that the averages of parents and hybrids of the diallel were different from the controls. The non-significance for PE indicates that there was no difference between the parents and hybrids of the diallel compared to control means (respective means of 19.33 and $19.29 \mathrm{~mL} / \mathrm{g}$ ).

The traits GY and PE were significant for the treatment-by-year and genotype-byyear interactions, indicating that the genotypes performed differently in the two growing seasons.

The statistical difference for PE in the interactions parents-by-year and hybrid-byyear is worth mentioning. Only GY was significant for the former, denoting that the hybrids were less sensitive to variations between growing seasons than the diallel parents.

The genotype-control-location interaction showed that the mean of the parents and hybrids of the diallel differed from the mean of the controls in the locations for all traits evaluated. Since the analysis of the genotype-by-control interaction denoted dissimilarity for GY and PHE, it was concluded that the evaluation in distinct environments favored the detection of differences in the genotypes studied.

The analysis of the treatment-location-year interaction revealed differences between the treatments evaluated in the different localities and growing seasons for GY, NBP and PE; likewise, the genotype-location-year interaction suggested that the dissimilarity observed for these triple interactions was influenced by the cultivation in different years.

The parent-location-year interaction indicated significance for GY and NBP, while hybrid-location-year only for GY, which is evidence that the parents and mainly the hybrids were not very dissimilar when evaluated in different years and locations. This is corroborated by the parent-hybrid-location-year contrast, in which only GY was statistically different.

In relation to the genetic parameters, considering the main traits for breeding, GY and PE, the high values of the coefficient of genotype determination (Table 2) indicate the possibility of selection gains with the application of simpler breeding methods. The 
values of the variation index corroborate this assumption ( 0.97 for GY and 1.81 for PE), demonstrating that the phenotype clearly expressed the genotype.

\begin{tabular}{|c|c|c|c|c|c|c|}
\hline \multirow[t]{2}{*}{ Traits } & \multicolumn{6}{|c|}{ Genetic parameters } \\
\hline & $\hat{\sigma}_{f(\bar{x})}^{2}$ & $\hat{\sigma}_{r(\bar{x})}^{2}$ & $\hat{\Phi}_{g}$ & $\hat{\sigma}_{g e}^{2}$ & $\hat{H}^{2}$ & $\hat{I}_{v}$ \\
\hline$\overline{\mathrm{GY}}$ & $104,024.07$ & $6,396.29$ & $97,627.78$ & $26,934.80$ & 93.95 & 0.97 \\
\hline NBP & 10.51 & 2.18 & 8.33 & 1.96 & 79.25 & 0.48 \\
\hline PHE & 0.26 & 0.16 & 0.10 & 0.09 & 38.46 & 0.20 \\
\hline PE & 18.32 & 0.34 & 17.98 & 1.11 & 98.14 & 1.81 \\
\hline
\end{tabular}

As for NBP and mainly for PHE, due to the lower magnitudes of $\hat{H}^{2}$ (coefficient of genotype determination) and $\hat{I}_{v}$ (variation index), care must be taken with the indication of selection methods for satisfactory gains. By any means, a popcorn breeder must pay attention not only to grain yield and popping expansion but also to other traits of interest for the crop as well (e.g., number of broken plants and number of partially husked ears). In this case, the breeding method cannot be very simple and neither can direct selection be considered an appropriate procedure. As to the breeding strategy, the results of selection among and within half-sib families were promising in recurrent selection procedures in popcorn in the country, representing the most widely applied method in Brazil (Zinsly, 1969; Lira, 1983; Galvão et al., 2000). The method is preferred owing to the ease of use, besides the efficiency in increasing the frequencies of favorable alleles in the populations, as demonstrated by Matta and Viana (2003).

Pereira and Amaral Júnior (2001) determined the best possibilities of predicted gains for the conditions of the northern and northwestern Fluminense region, in an evaluation of 92 progenies of Design I of the base population UNB-2U, ranking the recurrent methods, as follows: full-sib families, $\mathrm{S}_{1}$ progenies, half-sib families, and stratified mass selection. Consequently, the intrapopulation method with selection of full-sib families seems adequate, since higher gains will be obtained (Balestre et al., 2008). Additionally, the strategy of selection index should be used to select the best progenies for the recombination. By the selection index, it is possible to please producers with increased yields and stands with less broken and partially husked ears and, concomitantly, satisfy consumers with a greater popping expansion of the product, since the robustness of the analytic procedure of the selection index exceeds the negative signal of correlations between the traits of interest, as is the case with GY and PE in popcorn.

In the Scott-Knott cluster analysis (Table 3), the expressions of the traits in the cultivations were considered interesting in set, rather than in a particular year or location per se, in spite of the statistical significance of parents-location-year for GY and NBP ( 5 and $1 \%$, respectively) and hybrid-location-year for GY (at 5\% probability) (Table 1). This concept was based on the fact that the study target is the future release of a cultivar adaptable to the northern and northwestern Fluminense region, which implies the need to consider the performance of the genotypes in location and years simultaneously. 


\begin{tabular}{|c|c|c|c|c|c|c|c|c|}
\hline \multirow[t]{2}{*}{ Genotype } & \multicolumn{2}{|c|}{ GY } & \multicolumn{2}{|c|}{ NBP } & \multicolumn{2}{|c|}{ PHE } & \multicolumn{2}{|c|}{$\mathrm{PE}$} \\
\hline & Means & $\hat{H}_{M P(\%)}$ & Means & $\hat{H}_{M P(\%)}$ & Means & $\hat{H}_{M P(\%)}$ & Means & $\hat{H}_{M P(\%)}$ \\
\hline 1 & $1,307.81^{\mathrm{A}}$ & - & $13.38^{\mathrm{A}}$ & - & $2.00^{\mathrm{A}}$ & - & $22.68^{\mathrm{C}}$ & - \\
\hline 2 & $576.88^{\mathrm{B}}$ & - & $22.00^{\mathrm{A}}$ & - & $2.32^{\mathrm{A}}$ & - & $16.93^{\mathrm{D}}$ & - \\
\hline 3 & $1,099.38^{\mathrm{A}}$ & - & $15.63^{\mathrm{A}}$ & - & $2.19^{\mathrm{A}}$ & - & $16.56^{\mathrm{E}}$ & - \\
\hline 4 & $512.50^{\mathrm{B}}$ & - & $11.00^{\mathrm{A}}$ & - & $1.25^{\mathrm{A}}$ & - & $12.89^{\mathrm{E}}$ & - \\
\hline 5 & $681.25^{\mathrm{B}}$ & - & $17.50^{\mathrm{A}}$ & - & $2.82^{\mathrm{A}}$ & - & $17.57^{\mathrm{D}}$ & - \\
\hline 6 & $1,032.82^{\mathrm{A}}$ & - & $11.82^{\mathrm{A}}$ & - & $1.87^{\mathrm{A}}$ & - & $30.77^{\mathrm{A}}$ & - \\
\hline 7 & $910.00^{\mathrm{B}}$ & - & $13.88^{\mathrm{A}}$ & - & $1.75^{\mathrm{A}}$ & - & $19.63^{\mathrm{D}}$ & - \\
\hline 8 & $1,288.43^{\mathrm{B}}$ & - & $11.82^{\mathrm{A}}$ & - & $1.63^{\mathrm{A}}$ & - & $23.38^{\mathrm{C}}$ & - \\
\hline 9 & $645.94^{\mathrm{B}}$ & - & $9.13^{\mathrm{A}}$ & - & $2.56^{\mathrm{A}}$ & - & $15.81^{\mathrm{E}}$ & - \\
\hline 10 & $1,215.31^{\mathrm{A}}$ & - & $15.63^{\mathrm{A}}$ & - & $3.44^{\mathrm{A}}$ & - & $19.93^{\mathrm{D}}$ & - \\
\hline $1 \times 5$ & $1,343.75^{\mathrm{A}}$ & 35.12 & $13.19^{\mathrm{A}}$ & -14.57 & $2.56^{\mathrm{A}}$ & 6.22 & $21.76^{\mathrm{C}}$ & 8.12 \\
\hline $1 \times 6$ & $1,721.88^{\mathrm{A}}$ & 47.13 & $10.88^{\mathrm{A}}$ & -13.65 & $1.75^{\mathrm{A}}$ & -9.56 & $26.01^{\mathrm{B}}$ & -2.67 \\
\hline $1 \times 7$ & $1,416.25^{\mathrm{A}}$ & 27.72 & $15.13^{\mathrm{A}}$ & 11.00 & $3.06^{\mathrm{A}}$ & 63.20 & $20.71^{\mathrm{D}}$ & -2.10 \\
\hline $2 \times 6$ & $1,393.75^{\mathrm{A}}$ & 73.17 & $15.63^{\mathrm{A}}$ & -7.57 & $2.06^{\mathrm{A}}$ & -1.67 & $25.73^{\mathrm{B}}$ & 7.88 \\
\hline $2 \times 7$ & $1,072.82^{\mathrm{A}}$ & 44.30 & $17.38^{\mathrm{A}}$ & -3.12 & $2.93^{\mathrm{A}}$ & 43.98 & $18.21^{\mathrm{D}}$ & -0.38 \\
\hline $2 \times 8$ & $1,333.44^{\mathrm{A}}$ & 42.98 & $14.94^{\mathrm{A}}$ & -11.65 & $1.37^{\mathrm{A}}$ & -30.63 & $20.31^{\mathrm{D}}$ & 0.77 \\
\hline $3 \times 7$ & $1,299.38^{\mathrm{A}}$ & 29.33 & $14.75^{\mathrm{A}}$ & -0.03 & $3.00^{\mathrm{A}}$ & 52.28 & $17.02^{\mathrm{D}}$ & -5.94 \\
\hline $3 \times 8$ & $1,649.07^{\mathrm{A}}$ & 38.13 & $12.88^{\mathrm{A}}$ & -6.16 & $2.68^{\mathrm{A}}$ & 40.31 & $19.37^{\mathrm{D}}$ & -3.00 \\
\hline $3 \times 9$ & $1,624.07^{\mathrm{A}}$ & 86.11 & $10.50^{\mathrm{A}}$ & -15.19 & $3.00^{\mathrm{A}}$ & 26.32 & $14.16^{\mathrm{E}}$ & -12.52 \\
\hline $4 \times 8$ & $1,590.63^{\mathrm{A}}$ & 47.74 & $12.38^{\mathrm{A}}$ & 8.50 & $2.25^{\mathrm{A}}$ & 108.33 & $17.66^{\mathrm{D}}$ & -2.62 \\
\hline $4 \times 9$ & $1,330.32^{\mathrm{A}}$ & 129.67 & $7.94^{\mathrm{A}}$ & -21.11 & $1.94^{\mathrm{A}}$ & 1.84 & $14.33^{\mathrm{E}}$ & -0.14 \\
\hline $4 \times 10$ & $1,651.88^{\mathrm{A}}$ & 91.21 & $13.50^{\mathrm{A}}$ & 1.39 & $2.50^{\mathrm{A}}$ & 6.61 & $15.69^{\mathrm{E}}$ & -4.38 \\
\hline $5 \times 9$ & $1,372.50^{\mathrm{A}}$ & 106.83 & $14.56^{\mathrm{A}}$ & 8.60 & $2.81^{\mathrm{A}}$ & 4.46 & $13.89^{\mathrm{E}}$ & -16.77 \\
\hline $5 \times 10$ & $1,180.63^{\mathrm{A}}$ & 24.50 & $16.63^{\mathrm{A}}$ & 0.39 & $2.56^{\mathrm{A}}$ & -18.21 & $18.16^{\mathrm{D}}$ & -3.15 \\
\hline $6 \times 10$ & $1,423.43^{\mathrm{A}}$ & 26.63 & $11.94^{\mathrm{A}}$ & -13.00 & $2.12^{\mathrm{A}}$ & -20.15 & $23.11^{\mathrm{C}}$ & -8.84 \\
\hline
\end{tabular}

Means followed by the same letter belonging to the same group did not differ from each other by the Scott-Knott procedure, at $5 \%$ probability. $\mathrm{GY}=$ grain yield, in $\mathrm{kg} / \mathrm{ha} ; \mathrm{NBP}=$ number of broken plants; $\mathrm{PHE}=$ partially husked ears; $\mathrm{PE}=$ popping expansion, in $\mathrm{mL} / \mathrm{g} .1$ = UNB2U-C1; 2 = PR Ervália; 3 = Viçosa-UENF; 4 = PA038-Maringá; 5 =White-Viçosa; 6 = BRS Angela; 7 = Beija-Flor; 8 = UNB2U-C2; 9 = SE013-Maringá; 10 = Viçosa-Viçosa.

For GY, all estimates of the relative heterosis were positive, and interestingly, in only one pair (White-Viçosa x Viçosa-Viçosa) was there no heterobeltiosis effect. In an evaluation of hybrids derived from complete diallel crosses among nine parents for the trait grain yield (growing season 1998/1999), Scapim et al. (2002) found heterobeltiosis in 25 of 36 possible combinations. This confirms the argument that heterobeltiosis for GY may be a common effect in popcorn and shows that the parents that have been used in diallel cross systems may belong to distinct gene pools. Moreover, the occurrence of positive values in all combinations in this study and the higher positive heterotic values found by Andrade et al. (2002), Scapim et al. (2002) and Miranda et al. (2008) reinforce the assertion that dominance effects are essential to obtain GY gains in popcorn.

Among the hybrids, although higher heterotic effects were expressed by other pairs, the means of the combination UNB2U-C1 x BRS Angela were the highest in absolute terms in the evaluations in different locations and years and seems promising with the aim of experimental use in the northern and northwestern Fluminense region.

The magnitude of the experimental coefficient of variation (CVe) for GY decreased between the trial of 2003/2004 (Freitas Júnior et al., 2006) and the joint analysis of the 2003/2004 and 2004/2005 growing seasons, expressed in the respective values of 28.91 and $26.16 \%$ (Table 
1). Cargnelutti Filho and Storck (2007) ascribe this to the fact that, according to the propriety of the mathematical expectation, when adding a constant to a variable, the new mean is to be added to this constant; thus, the variance remains unchanged, while the CVe decreases.

For the number of broken plants, a greater quantity than the $66.66 \%$ of the hybrids that exhibited negative heterosis was expected (Table 3), since the influence of the additive effects is far greater in the trait expression, as stated by Freitas Júnior et al. (2006) and Rangel et al. (2007). A possible reason for the expression of this result can be explained by the high percentage of CVe for NBP (Table 1). This value, considered very high by Scapim et al. (1995), denoted considerable variation within treatments for the trait in question, which interferes with more accurate presuppositions on the number of broken plants. The estimates of heterosis for 10 of the 15 hybrids were positive (Table 3), among them UNB2U-C1 x BRS Angela, ViçosaUENF x UNB2U-C2 and Viçosa-UENF x SE013-Maringá, with outstanding grain yield.

For PHE, Freitas Júnior et al. (2006) found values close to the mean squares of GCA and SCA effects, with slightly higher dominance effects (0.1273 compared to 0.1352 , respectively) in the evaluation of the treatments in question in the 2003/2004 growing season. Rangel et al. (2007) further stated that in the joint analysis of the 2003/2004 and 2004/2005 growing seasons, the mean squares of the GCA and SCA effects were practically equal, with only slightly higher additive effects ( 0.0772 compared to 0.0637 , respectively). Considering that the dominance and additive effects are equivalent in the expression of PHE, the existence of a bidirectional dominance effect may be assumed, although not as absolute, due to the negative heterosis estimates of 5 of the 15 hybrids (Table 3). Once more, in relation to the coefficient of experimental variation, the highest CVe value was found for trait PHE (Table 1), which explains the possibility of selection of only one superior hybrid for GY and PHE, from the set of the above-cited: UNB2U-C1 x BRS Angela.

The interaction genotype by location for PE indicates that the genotypes behaved similarly in relation to the changes in edaphoclimatic conditions, supporting the idea of Alexander and Creech (1977) that the expansion phenomenon is a polygenic trait, but subject to a low environmental influence. However, Robbins and Ashman (1984) suggested that the environmental influence seems to be relevant to PE, since there is evidence that not all the genes that contribute to endosperm hardness also contribute to PE, which suggests that the adaptation to the growing area influences the capability of expansion of the popcorn kernel.

On the other hand, considering the interaction with year for PE, treatment-year and treatment-location-year were significant at $1 \%$ probability (Table 1 ). These results are different from that obtained by Miranda et al. (2008), where there were similar edaphoclimatic conditions studied in a complete diallel scheme.

For popping expansion, the heterotic values of only three combinations were positive, which ratifies the greater importance of additive effects in PE expression, corroborating the findings by Pereira and Amaral Júnior (2001), Matta and Viana (2003), Simon et al. (2004), and Freitas Júnior et al. (2006). Miranda et al. (2008) confirmed that there was reduced heterosis for PE in Brazilian popcorn populations in relation to commercial cultivars. However, these results must be considered with caution, because the hypothesis of bidirectional dominance on the effect of PE cannot be refuted.

The present results indicate that intrapopulation breeding for PE may offer superior genetic gains; however, for GY interpopulation breeding is required, in agreement with Pereira and Amaral Júnior (2001). 
Based on the set of traits evaluated, the hybrid UNB2U-C1 x BRS Angela may be indicated for experimental cultivation in the northern and northwestern Fluminense region.

\section{ACKNOWLEDGMENTS}

The authors thank Conselho Nacional de Pesquisa (CNPq) and Fundação de Amparo à Pesquisa do Estado do Rio (FAPERJ) for financial support.

\section{REFERENCES}

Alexander DE and Creech RG (1977). Breeding Special Industrial and Nutritional Types. In: Corn and Corn Improvement (Sprag GF and Fuccilo DA, eds.). American Society of Agronomy, Madison, 363-386.

Andrade RA, Cruz CD, Scapim CA, Silvério L, et al. (2002). Análise dialélica da capacidade combinatória de variedades de milho-pipoca. Acta Scientiarum 24: 1197-1204.

Balestre M, Machado JC, Lima JL, Souza JC, et al. (2008). Genetic distance estimates among single cross hybrids and correlation with specific combining ability and yield in corn double cross hybrids. Genet. Mol. Res. 7: 65-73.

Cargnelutti Filho A and Storck L (2007). Estatísticas de avaliação da precisão experimental em ensaios de cultivares de milho. Pesq. Agropec. Bras. 42: 17-24.

Cruz CD (2006). Programa Genes - Biometria. Editora UFV, Viçosa.

Cruz JC and Pereira Filho IA (2008). Cultivares de milho disponíveis no mercado de sementes do Brasil para a safra 2006/2007. In: Embrapa Milho e Sorgo, Sete Lagoas. [http://www.cnpms.embrapa.br/milho/cultivares/index.php].

Cruz CD, Regazzi AJ and Carneiro PCS (2004). Modelos biométricos aplicados ao melhoramento genético. Editora UFV, Viçosa.

Daros M, Amaral Júnior AT, Pereira MG, Santos FS, et al. (2004). Recurrent selection in inbred popcorn families. Sci. Agricola 61: 609-614.

Ferreira FM, Ribeiro Júnior JI, Pacheco CAP, Silva CHO, et al. (2004). Efficiency of circulant diallels as compared to complete diallels for the estimation of general and specific combining ability. Crop. Breed. Appl. Biotechnol. 2: 141-151.

Freitas Júnior SP, Amaral Júnior AT, Pereira MG, Cruz CD, et al. (2006). Capacidade combinatória em milho pipoca por meio de dialelo circulante. Pesq. Agropec. Bras. 41: 1599-1607.

Galvão JC, Sawazaki E and Miranda GV (2000). Comportamento de híbridos de milho pipoca em Coimbra, Minas Gerais. Rev. Ceres 47: 201-218.

Hallauer AR and Miranda Filho JB (1995). Quantitative Genetics in Maize Breeding. 2nd edn. Iowa State University Press, Ames.

Kempthorne O and Curnow RN (1961). The partial diallel cross. Biometrics 17: 229-250.

Lira MA (1983). Seleção entre e dentro de famílias de meio-irmãos para produção e capacidade de expansão e correlações entre alguns caracteres em milho pipoca (Zea mays L.). Master's thesis, Universidade Federal de Lavras, Lavras.

Matta FP and Viana JMS (2003). Eficiências relativas dos processos de seleção entre e dentro de famílias de meios-irmãos em população de milho-pipoca. Ciênc. Agrotec. 27: 548-556.

Miranda GV, Souza LV, Galvão JCC, Guimarães LJM, et al. (2008). Genetic variability and heterotic groups of Brazilian popcorn populations. Euphytica 159: 123-132.

Pereira MG and Amaral Júnior AT (2001). Estimation of genetic components in popcorn based on the nested design. Crop. Breed. Appl. Biotechnol. 1: 3-10.

Rangel RM, Amaral Júnior AT, Viana AP, Freitas Júnior SP, et al. (2007). Prediction of popcorn hybrid and composite means. Crop. Breed. Appl. Biotechnol. 7: 288-296.

Ricci GC, Silva N, Pagliarini MS and Scapim CA (2007). Microsporogenesis in inbred line of popcorn (Zea mays L.). Genet. Mol. Res. 6: 1013-1018.

Robbins WA Jr and Ashman RB (1984). Parent-offspring popping expansion correlations in progeny of dent corn $\mathrm{x}$ popcorn and flint corn x popcorn crosses. Crop Sci. 24: 119-121.

Sawazaki E (2001). A cultura do milho-pipoca no Brasil. Agronômico 53: 11-13.

Sawazaki E, Paterniani MEAGZ, Castro JL, Gallo PB, et al. (2000). Potencial de linhagens locais de milho-pipoca para síntese de híbridos. Bragantia 59: 143-151. 
Sawazaki E, Fantin GM, Dudienas C, Castro JL, et al. (2003). Resistência de genótipos de milho pipoca a doenças. Rev. Agricultura 78: 149-164.

Scapim CA, Carvalho CGP and Cruz CD (1995). Uma proposta de classificação dos coeficientes de variação para a cultura do milho. Pesq. Agropec. Bras. 30: 683-686.

Scapim CA, Pacheco CAP, Tonet A, Braccini AL, et al. (2002). Análise dialélica e heterose de populações de milho pipoca. Bragantia 61: 219-230.

Simon GA, Scapim CA, Pacheco CAP, Pinto RJB, et al. (2004). Depressão por endogamia em populações de milhopipoca. Bragantia 63: 55-62.

Veiga RD, Ferreira DF and Ramalho MAP (2000). Eficiência dos dialelos circulantes na escolha de genitores. Pesq. Agropec. Bras. 38: 1395-1406.

Vendrusculo ECG, Scapim CA, Pacheco CAP, Oliveira VRO, et al. (2001). Adaptabilidade e estabilidade de cultivares de milho-pipoca na região centro-sul do Brasil. Pesq. Agropec. Bras. 36: 123-130.

Zinsly JR (1969). Estudo comparativo entre a seleção massal e a seleção entre e dentro de famílias de meios-irmãos em milho (Zea mays L.). Doctoral thesis, USP/ESALQ, Piracicaba. 